\title{
Sähköistääkö vesivoima kansalaisyhteiskunnan Balkanilla?
}

Ympäristöaktivistit iloitsivat kuluvan vuoden kesäkuussa, kun Bosnia-Hertsegovinan federaation parlamentti päätti esittää pienen mittakaavan vesivoiman rakentamisen kieltämistä. Linjaus näyttää asettuvan esteeksi jopa noin 400 vesivoimahankkeelle, joita on suunniteltu eri puolille maan jo varsin tiiviisti energiantuotantoon valjastettuja jokia. Toteutuessaan voimaloilla olisi ollut herkkään luontoon ja kokonaisiin ekosysteemeihin peruuttamattomia haittavaikutuksia, joita vastaan ympäristöjärjestöt ja paikalliset asukkaat ovat kampanjoineet jo pitkään.

Vesivoimapäätöstä on kuvattu valonpilkahdukseksi Balkanin muuten verrattain synkältä näyttävässä kansalaisyhteiskuntakehityksessä. Alueen maat ovat pikemminkin luisuneet entistä autoritaarisempaan suuntaan, ja luottamus demokraattiseen hallintoon on heikentynyt. Esimerkiksi EU-jäsenyysprosessissa usein Balkanin maista edelläkävijänä pidetty Serbia putosi Freedom Housen ylläpitämässä luokituksessa tänä vuonna "vapaasta" demokratiasta "osittain vapaaksi" - ensimmäistä kertaa sitten vuoden 2003. Osaa alueen maista vaivaavat rakenteelliset ja 1990-luvun konflikteista juontuvat kiistat.

Omaehtoisen kansalaistoiminnan aikaansaamat muutokset herättävätkin toivoa erityisesti Bosnia-Hertsegovinassa, jossa vuoden 1995 rauhansopimukseen perustuva, monimutkainen hallintorakenne on osaltaan ruokkinut korruptiota ja pönkittänyt oman edun tavoitteluun keskittyvien poliitikkojen asemaa. Jos kansan on mahdollista saada äänensä olosuhteista huolimatta kuuluviin ympäristöasioissa, voivat vastaavat kansalaisvaikuttamisen muodot ainakin teoriassa toimia myös muunlaisissa kysymyksissä. Itäisen Euroopan maissa ajatuksella ympäristöaktivismista laajemman kansalaistoiminnan ja jopa kansalaisvastarinnan edelläkävijänä on erityistä kaikupohjaa historiasta, sillä ympäristöön liittyvillä protesteilla oli rooli sosialismin kaatumiseen johtaneessa liikehdinnässä.

Ympäristön ja demokratian välinen suhde korostuu ilmastonmuutoksen ja muiden ekologisten kriisien myötä maailmanlaajuisesti, eikä se suinkaan rajoitu ympäristöaktivismin vaikutusmahdollisuuksiin yksittäisissä kysymyksissä. Tarkemmin katsottuna edellä mainittu vesivoiman vastainen liikehdintä valottaa hyvin aiheiseen liittyviä, usein monimutkaisia vaikutusketjuja. Bosnia-Hertsegovinassa vesivoiman lisärakentamista on perusteltu osana ilmastonmuutoksen hillintää ja kestävää energiantuotantoa, sillä siitä ei aiheudu kasvihuonekaasupäästöjä. Koko liittovaltion tavoitteena on ollut nostaa uusiutuvan energian osuus 40 
prosenttiin kaikesta energiankulutuksesta vuoteen 2020 mennessä, ja vesivoimalla on suunnitelmissa tärkeä rooli. Tavoite ei ole toteutumassa ajallaan, eikä vesivoiman rakentamisen vaikeuttaminen ainakaan helpota tilannetta. Tältä kannalta näyttääkin hiukan nurinkurisesti siltä, että ympäristöjärjestöjen toiminta on haitannut ilmastonmuutoksen hillintää.

Laajemmasta ekologisesta näkökulmasta vesivoima ei kuitenkaan missään nimessä ole ongelmaton vaihtoehto. Sen edellyttämät padot vaikuttavat laajasti lähiympäristöön ja saattavat muuttaa kokonaisia ekosysteemejä peruuttamattomasti. Riski on erityisen suuri Bosnia-Hertsegovinassa, missä täysin luonnontilassa olevia jokia on jäljellä verrattain vähän, ja padot ovat jo nyt tuhonneet ainutlaatuisia luontokohteita. Ekologisten arvojen lisäksi uhattuna saattaa joskus olla myös taloudellinen toimeentulo, sillä jokiluonnosta ovat riippuvaisia monet elinkeinot, kuten turismi ja kalastus. Vesivoiman tuotannon lisäämisen vaikutukset ovat käyneet niin laajoiksi ja näkyviksi ettei niitä pysty sivuuttamaan. Tilanne heijastaa viime vuosina tutkimuksessa korostettua näkemystä, jonka mukaan ilmastonmuutoksen hillintä ei voi olla kestävällä pohjalla, mikäli siitä seuraa kohtuutonta haittaa muuhun ympäristöön tai jollekin yhteiskunnalliselle ryhmälle.

Demokraattinen päätöksentekojärjestelmä nousee avainasemaan hahmotettaessa edellytyksiä kestävälle siirtymälle kohti hiilineutraalia yhteiskuntaa, sillä se mahdollistaa avoimen keskustelun ilmastopolitiikasta ja sen seurauksista. Päästövähennystoimien toteutus saattaa sujua nopeammin epädemokraattisessa järjestelmässä, jossa tarve poliittisille kompromisseille ei ole niin suuri, mutta samalla niiden haittapuolet jäävät helpommin pimentoon. Todennäköistä kuitenkin on, että jossain vaiheessa vaietut vaikutukset käyvät sietämättömiksi ja johtavat esimerkiksi protesteihin tai ympäristötuhoihin. Siksi niitä olisi syytä käsitellä hyvissä ajoin ja tarvittaessa tehdä pyörtäviä päätöksiä, kuten Bosnia-Hertsegovinan tapauksessa.

Demokratia kuitenkin tarvitsee toimiakseen paitsi kansalaisyhteiskunnan aktiivisuutta, myös hyvää hallintoa. Tehokas siirtymä vähäpäästöisyyteen tuo väistämättä mukanaan tilanteita, joissa pitkän tähtäimen kannalta aidosti hyödylliset ja kestävät ratkaisut eivät kerää tuekseen kansanliikettä. Toisaalta kiivaskaan aktivismi ei auta, jos poliittinen järjestelmä ei kykene tekemään päätöksiä tai toimeenpanemaan niitä. Ilmastonmuutoksen hillintä ei siten voi olla pelkästään kansalaistoiminnan varassa. Siksi Balkanin maiden heikentyvä demokratiakehitys on huolestuttavaa myös ilmasto- ja ympäristötavoitteiden toteuttamisen kannalta. Vaikka Bosnia-Hertsegovinan vesivoimapäätös herättää toivoa aktivistien vaikutusmahdollisuuksista, vaatii oikeudenmukainen ja pitkäjänteinen ympäristöpolitiikka laajempaa järjestelmätason yhteistoimintaa. Demokratian rapautuminen koituu lopulta myös ympäristön ja ilmaston tappioksi.

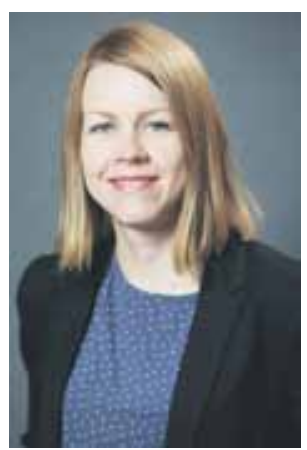

Emma Hakala

Kirjoittaja on väitellyt poliittisesta historiasta Helsingin yliopistossa vuonna 2018. Hän työskentelee tutkijana BIOS-tutkimusyksikössä ja vierailevana vanhempana tutkijana Ulkopoliittisessa instituutissa. 